\title{
Introduktion: Politiske partier på tværs af perspektiver
}

Emil Husted, adjunkt, Institut for Ledelse, Politik og Filosofi, Copenhagen Business School

En terminalpatient vækkes til live

Det er efterhånden blevet en kliché at hævde, at politiske partier er en uddøende race, og at deres hierarkiske strukturer og manglende omstillingsparathed har gjort dem ukampdygtige i et samfund, hvor det eneste konstante er forandring. Dette er om ikke andet konklusionen i en lang række akademiske tekster (f.eks. Della Porta 2013; Hardt og Negri 2017; Rosavallon 2008), og håndfast empirisk data synes da også at understøtte fortællingen om partiernes endeligt. Færre og færre mennesker figurerer eksempelvis som medlemmer af politiske partier (van Biezen et al. 2012), ligesom at valgdeltagelsen på verdensplan er styrdykket siden midten af det forrige århundrede (Solijnov 2016). Dertil kommer, at tilliden til vores folkevalgte har ramt bunden i kølvandet på Brexit og indsættelsen af Donald Trump som USA's nuværende præsident. Faktisk anses politikere i dag ofte for værende mindre tillidsvækkende end totalt fremmede og mere uærlige end brugtvognsforhandlere (Newton et al., 2017). Det kan dermed synes relativt ligetil at konkludere, at partiernes tid er forbi, og at de inden længe vil blive afløst af mere horisontale og responsive formationer, og at vi som samfund måske endda nærmer os 'the end of representative politics' (Tormey 2015).

Men for nu at parafrasere Mark Twain, så er nyhederne om partiernes død stærkt overdrevne. Finansielt har partierne eksempelvis aldrig været stærkere. Dette skyldes i mange lande en gradvis stigning i offentlig støtte siden 1980'erne, hvilket har modvirket de hastigt faldende medlemsindtægter, men til gengæld skabt en kartel-lignende symbiose mellem staten og de politiske partier (Katz og Mair 1995). Som eksempel modtager mange europæiske partier i dag to-tredjedele af deres økonomiske støtte fra statslige subsidier (Falguera et al. 2014). Dertil kommer, at mange lande de seneste år har gennemgået en såkaldt 'konstitutionaliserings-proces', hvormed politiske partier er blevet anerkendt rent forfatningsmæssigt som nødvendige og ønskværdige aktører i et velfungerende demokrati (van Biezen 2011). Kombinationen af en grundliggende utilfredshed med partier og øget statslig konsolidering har således skabt en paradoksal situation, hvor de politiske partier står stærkere end tidligere lovmæssigt og økonomisk, men hvor de i stigende grad anses for illegitime repræsentanter for fællesskabets interesser (Ignazi 2017). 
Dette paradoks synes til gengæld at have givet plads til opblomstringen af en række nye formationer, der på forskellig vis eksperimenterer og innoverer inden for rammerne af bestående parti-systemer - ofte med et fokus på demokratisering. Podemos i Spanien, Femstjernebevægelsen i Italien, La France Insoumise, Piratpartiet i Island, Feministisk Initiativ i Sverige og Alternativet her i Danmark figurerer som prominente eksempler på denne tendens. Inspireret af de mange 'nye revolutioner' (Mason 2013) som f.eks. Occupy Wall Street og Los Indignados, der siden 2011 har præget den vestlige verden, har disse unge partier forsøgt at udbedre partipolitikkens dalende legitimitet ved at introducere nyskabende organisatoriske innovationer. Podemos har eksempelvis forsøgt at redefinere idéen om parti-internt demokrati ved at strukturere deres organisation omkring såkaldte 'Cirkler', hvor medlemmer og ikke-medlemmer kan deliberere om udvalgte politikområder uafhængigt af tydelig partidisciplin (Pavía et al. 2016). På samme måde har Alternativet herhjemme konstrueret store dele af deres partiprogram igennem en bottomup-proces, der trækker tråde til tankegangen bag 'open-source communities' i IT-verden (Husted og Plesner 2017).

Det er dog ikke kun på den progressive venstrefløj, at nye og innovative partiformationer har vundet indpas. I den modsatte ende af det politiske spektrum har en lignende tendens fundet sted. Her handler eksperimenterne dog knap så meget om demokratisering (selvom Femstjernebevægelsen givetvis er et eksempel på netop dette), men er snarere bundet op på stærke ledere og effektive beslutningsprocesser. Det kan eksempelvis observeres i det hollandske Frihedsparti, PVV, hvor formanden Geert Wilders er det eneste officielle medlem. Det samme gør sig gældende på den anden side af Nordsøen, hvor Nigel Farages nystartede Brexit Party kan bryste sig af en medlemsskare på hele tre personer: en politisk leder, en nomineringsansvarlig og en kasserer. Til gengæld har partiet efter eget udsagn mere end 100.000 følgere, der strategisk aktiveres via internettet, hvilket giver organisationen et skær af, hvad Paolo Gerbaudo $(2018,76)$ i hans bog om 'digitale' partier kalder 'distributed centralization' - klassisk oligarki forklædt som borgerinddragelse (se Loucaides 2019).

Denne underskov af nye partier, der på idiosynkratisk vis udfordrer den bestående konsensus om, hvad et politisk parti er for en størrelse, og hvordan den i øvrigt opererer, giver os en tiltrængt anledning til at danne os et overblik over partilitteraturen og genoverveje dens udsigelseskraft: Hvilke overordnede perspektiver er til rådighed for forskere og studerende, der interesserer sig for partier? Hvilke begreber stiller disse perspektiver til rådighed, og kan disse begreber indfange de mange partimæssige nybrud, vi p.t. kan observere? Hvad tillader disse begreber os derudover at se rent empirisk, og hvad gør vi os samtidig blinde overfor? Det er denne nysgerrighed, der ligger til grund for nærværende temanummer. 


\section{Partilitteraturen i perspektiv}

Selvom diskussioner om fraktioners rolle i vestlige demokratier kan spores tilbage til oldtidens Grækenland, hvor velkendte figurer som f.eks. Platon og Aristoteles fremhævede problemerne ved at opdele polis i konkurrerende grupper, skal vi helt frem til midten af det nittende århundrede for at kunne ane konturerne af en selvstændig partilitteratur (Ignazi 2017). Denne meget sene opblomstring af akademisk interesse skyldes givetvis en historisk negativ attitude over for partier, der af langt de fleste intellektuelle dengang blev anset som ødelæggende for samfundets sammenhængskraft. Fordi partier netop repræsenterer dele af samfundet - og dermed ikke hele samfundet - blev de set som kontroversielle og splidskabende aktører (ordet 'parti' kommer af det latinske partes, der netop betyder 'dele'). Nancy Rosenblum (2008) kæder denne negative attitude over for partier sammen med begrebet 'holism', der for hende betegner en utopisk (men altdominerende) forestilling om samfundet som et harmonisk hele, der kan repræsenteres af uafhængige og rationelle statsmænd. Som David Hume (2002 [1742], 33) udtrykte det i sit essay Of parties in general: "As much as legislators and founders of states ought to be honored and respected among men, as much ought the founders of sects and factions to be detested and hated".

Måske af den grund har megen partilitteratur for vane at indlede med referencer til en række 'founding fathers', som i starten af det tyvende århundrede forsøgte at anskue partier som empiriske fænomener, der måtte forstås i deres egen ret og dermed ikke blot som et uønsket biprodukt af masse-demokratiets fremkomst. Mens den russiske politiker og sociolog Moisei Ostrogorski (1902) formentlig var den første til at tage denne opgave seriøst, er det ofte tyskeren Robert Michels (1915), der fremhæves som grundlæggeren af det empiriske studie af politiske partier. Baseret primært på personlige erfaringer fra det tyske Socialdemokrati (SPD), identificerede Michels en række dynamikker, der ifølge ham var indlejret i selve idéen om formel politisk organisering. Den nok mest velkendte dynamik handler om partiernes interne magtstruktur, og hvordan denne synes at forandre sig i takt med, at et parti bliver modent og opnår indflydelse. Kort fortalt er Michels' tese, der siden er blevet kendt som 'oligarkiets jernlov', at partier med tiden vil bevæge sig imod en mere vertikal og dermed autoritær struktur. Dette skyldes ifølge Michels, at partiernes ledere besnæres og korrumperes af den realpolitiske magt, hvilket leder dem til at ofre partiets idealer i et forsøg på at fastholde netop denne magt. Dermed forskydes partiets mål fra reel politisk forandring til simpel selvbevarelse og personlig vinding, hvormed partiorganisationens eksistens går fra at være et middel til at blive et mål i sig selv.

Michels' jernlov har siden dengang ligget som et tungt tæppe over partilitteraturen og ikke just bidraget til at forbedre partiernes allerede blakkede ry i den akademiske verden. Dette afspejles tydeligt i andre store værker inden for denne tradition. Et eksempel er Maurice Duvergers (1954) forsøg på at systematisere og syntetisere studiet af politiske partier. Selvom franskmandens bidrag unægtelig må betegnes som en milepæl i litteraturen, rummer hans bog Political parties tydelige referencer til Michels hovedværk, der 
sjovt nok bærer samme titel. Eksempelvis tager Duverger udgangspunkt i partiernes organisatoriske struktur (alle partier bygger tilsyneladende på ét af fire basale elementer), i den forstand at partiernes lederskab og medlemsforståelse determineres af de strukturelle forhold, hvilket giver hans arbejde et noget statisk og delvist unuanceret præg. En lignende henvisning til Michels finder vi i et andet hovedværk i partilitteraturen, nemlig Angelo Panebiancos (1988) indflydelsesrige teori om partimæssig forandring - hvilket i øvrigt også bærer titlen Political parties. Modsat hans to forgængere introducerer Panebianco dog en mere dynamisk tilgang til partiforskningen. I stedet for at se et parti som en enhed, der opererer 'according to its own laws' (Duverger, 1954, 84), konceptualiserer han partier som dynamiske størrelser, der konstant påvirkes af den sammenhæng, de indgår i. Hvor Michels og Duverger således iagttog partier (og partisystemer) som determineret af organisatoriske strukturer, vender Panebianco bøtten og iagttager partiernes struktur som determineret af eksterne forhold.

Panebiancos intervention giver dermed anledning til formuleringen af et nyt forskningsprogram, der ikke handler om at forstå politiske partier som afgrænsede enheder, der kan analyseres igennem 'single case'-studier, men som snarere handler om at forstå partierne i en større sammenhæng. Dette nye perspektiv kalder Panebianco (1988, xiv) for en 'komparativ-historisk' tilgang. Her handler det med andre ord om at forstå et parti $\mathrm{i}$ henhold til dets omverden (f.eks. andre partier) og til dets historie (f.eks. tidligere beslutninger). Dette forskningsprogram fik for alvor vind i sejlene med Richard Katz og Peter Mairs (1994) kendte antologi, How parties organize, hvori de beskriver behovet for en mere systematisk og empirisk kvantificerbar forståelse af partimæssig organisering og forandring. I forbindelse med formuleringen af denne ambition traf Katz og Mair et afgørende valg, som kom til at have stor indflydelse på fremtidens partiforskning. I stedet for som tidligere at basere empiriske undersøgelser af partier på et bredt udvalg af datakilder - fra statistik og dokumenter til personlige samtaler og deltagerobservation - valgte de to at fokusere udelukkende på 'the official stories' (Katz og Mair 1992, 7); altså, autoriseret data produceret af partierne selv. Denne dataudvælgelse sikrede ikke bare konsistens på tværs af datasæt, men gjorde det også muligt at kvantificere partiernes udvikling og sammenholde denne udvikling med partier i andre lande (Scarrow og Webb 2017). Til gengæld nedprioriterede den en mere kvalitativ forståelse af partiernes 'indre liv' (Barling 2013) og vendte det blinde øje til dynamikker, der udspiller sig 'deliberately out of the public eye' (Noel 2010, 63).

I dag er det komparative perspektiv med længder det mest dominerende perspektiv i partilitteraturen. Et hurtigt opslag i tidsskriftet Party Politics, hvis allerførste artikel netop er forfattet af Katz og Mair (1995), afslører da også, at langt de fleste bidrag beskæftiger sig med kvantificerbare sammenligninger af partier på tværs af tid og sted, og at meget få bidrag engagerer sig i kvalitative analyser af enkeltstående partier. Til gengæld er interessen for partier på det seneste begyndt at spire inden for mange forskellige akademiske discipliner. Som bidragene i dette temanummer viser, hører studiet af partiet ikke længere kun hjemme i politologien (hvor det komparative perspektiv ofte bor), selvom størstedelen af partiforskningen stadig kommer fra dette hjørne af videnskaben. 
Eksempelvis har den politiske teori på det seneste genopdaget det politiske parti som et interessant fænomen, ligesom at sociologien og medievidenskaben også er begyndt at fatte interesse for partiernes politik, organisering og kommunikation. Samme tendens kan jeg bekræfte inden for mit eget felt, organisationsstudier, hvor en gruppe af særligt yngre forskere har givet sig i kast med at formulere en eksplicit organisatorisk tilgang til studiet af politiske partier (f.eks. Moufahim et al. 2015; Husted 2018; Ringel 2019). Som jeg selv og andre har argumenteret for, kan denne tilgang beskrives som 'immersiv', da den netop retter sig mod en dybdegående og kvalitativ forståelse af partiernes interne dynamikker (Husted 2019).

\section{Temanummerets artikler}

I stedet for at starte med det p.t. mest dominerende perspektiv, tager dette temanummer et skridt tilbage og lægger ud med en artikel, der trækker partilitteraturen tilbage til sit oprindelige udgangspunkt i politisk og demokratisk teori. Temanummerets første artikel, skrevet af Fabio Wolkenstein (2019) fra Aarhus Universitet, starter således med at understrege det problematiske $i$, at politiske teoretikere ofte overser partier som relevante og interessante genstandsfelter. Hurtigt bevæger han sig dog videre til en diskussion af den spirende interesse for partier, som trods alt kan observeres inden for politisk teori som fagfelt. Igennem denne diskussion indsætter Wolkenstein en distinktion mellem studier, der iagttager 'partisanship' (parti-medlemskab eller parti-ånd) som en associativ praksis, og studier, der fokuserer på partier som særegne institutioner i det repræsentative demokrati. Artiklens overordnede argument er, at politiske teoretikere ofte prioriterer førstnævnte på bekostning af sidstnævnte, hvilket forhindrer os i at udvikle en mere generel forståelse af partiernes forhold til hinanden og til staten, samt hvordan det politiske parti som institution kan tænkes som et demokratisk mikrokosmos.

Temanummerets anden artikel, skrevet af Anika Gauja og Karina Kosiara-Pedersen (2019) fra hhv. University of Sydney og Københavns Universitet, udfolder politologiens komparative blik på politiske partier. Artiklen anlægger et historisk perspektiv og beskriver igennem dette udviklingen af et fagfelt, der går fra homogenitet og generalisering til heterogenitet og specialisering. Pointen er dermed at vise, at det komparative blik i dag sjældent producerer den slags overordnede teoretiseringer, som ovenfor blev associeret med Michels, Duverger og Panebianco. I stedet fokuserer feltet i dag på mere afgrænsede problemstillinger og spørger eksempelvis til partiernes ledelsesstrukturer, regler for kandidatudvælgelse, konstruktioner af partimedlemskab og kilder til finansiering. Givetvis grundet dette mere specialiserede fokus arbejder det komparative blik primært med kvantitative metoder, da numerisk data typisk egner sig bedre til formelle sammenligninger på tværs af tid og sted. Ligesom i temanummerets første artikel, diskuterer Gauja og Kosiara-Pedersen dog afslutningsvist en række nye udviklinger i feltet. Her viser de blandt andet, hvordan digitale teknologier har hjulpet forskere til at undersøge fremkomsten af nye tilknytningsformer og øget personalisering inden for partipolitikken. 
Temanummerets tredje artikel, skrevet af et forskerhold bestående af Leopold Ringel (Universität Bielefeld), Jan Schank (Universität Freiburg), Damien Krichewsky (Universität Bonn) og Jenni Brichzin (Technische Universität Chemnitz), leverer et overblik over de forskellige muligheder, som sociologien stiller til rådighed for partiforskningen. Artiklen starter ud med at redegøre for det faktum, at sociologiske hoftænkere som f.eks. Robert Michels og Max Weber spillede en nøglerolle i tidlige studier af politiske partier. I løbet af de seneste 100 år er sociologien og partiforskningen dog langsomt men sikkert gledet fra hinanden, hvilket har resulteret $\mathrm{i}$ et uforløst potentiale for begge discipliner, som Ringel et al. (2019) nu forsøger at vække til live. I den forbindelse peger forfatterne på tre perspektiver, som partiforskere fremadrettet kunne antage. For det første kan sociologisk teori inspireret af f.eks. Niklas Luhmann og Pierre Bourdieu bruges til at forstå, hvordan partier er indlejret i mere overordnede samfundsmæssige strukturer og dynamikker. For det andet kan sociologien (ligesom organisationsteorien) hjælpe os til at beskrive de interne forhold i partier, og hvordan eksempelvis beslutningsprocesser udfolder sig i praksis. Sidst men ikke mindst kan et sociologisk praksis-orienteret perspektiv assistere os i undersøgelser af den partipolitiske profession, og hvordan denne rekonfigureres af skiftende materielle omgivelser og nye teknologiers digitale infrastruktur.

Temanummerets fjerde og sidste artikel, skrevet af Sander Andreas Schwartz (2019) fra Roskilde Universitet, introducerer medievidenskaben som et af de nyere perspektiver i partilitteraturen. Med afsæt i et omfangsrigt litteraturstudie af 89 akademiske artikler, inddeler Schwartz litteraturen om sociale mediers rolle i parlamentarisk politik i tre overordnede kategorier: (1) Studier der fokuserer på den politiske afsender - partier og politikere - og deres respektive kommunikationsstrategier; (2) Studier der fokuserer på, hvordan sociale medier kan skabe øget borgerengagement; (3) Studier der fokuserer på relationen mellem politikere/partier og traditionelle massemedier. Artiklens overordnede konklusion er, at litteraturen overvejende er pessimistisk i forhold til sociale mediers demokratiserende potentiale, men at dette givetvis skyldes, at forskere ofte overser den langsomme og inkrementelle udvikling i forholdet mellem sociale medier og politik. Schwartz afslutter artiklen med at diskutere forskellige metodiske tilgange til studiet af parlamentarisk politik i et medieperspektiv. Her fremhæver han særligt en kombination af kvantitative og kvalitative metoder som værende gunstig for partiforskningen.

Flere overordnede tematikker går igen på tværs af de fire artikler. Et tema omhandler behovet for at forstå teknologiens rolle i moderne partipolitik. Som flere af artiklerne fremhæver, introducerer sociale medier og andre digitale teknologier et væld af muligheder for nutidens partier i forhold til medlemsinddragelse og strategisk kommunikation, men de præsenterer samtidig forskere med nogle svære spørgsmål i forhold til afgrænsningen af analytiske kategorier. Hvordan skal vi eksempelvis forstå konceptet 'partimedlemsskab' i en digital tidsalder, hvor grænsen mellem organisation og omverden udfordres af internettet, og hvor politik præges af en gennemgående personliggørelse? Et andet tema omhandler de mange organisatoriske og kommunikative innovationer, der p.t. kan observeres inden for forskellige partisystemer. Hvordan kan vi skærpe vores teoretiske værktøjer, så de passer til en tid, hvor nogle partier forsøger at inkludere hele det 
omkringliggende samfund i udviklingen af deres politik, mens andre partier opererer helt uden medlemmer? Et tredje tema omhandler behovet for at videreudvikle partilitteraturens metodiske værktøjskasse. Som nævnt tidligere i denne introduktion, og som det ligeledes fremhæves i artikel 2 (Gauja og Kosiara-Pedersen) og 3 (Ringel et al.), er partiforskningen i høj grad præget af kvantitative metoder, der tillader os at stille skarpt på ligheder og forskelligheder på tværs af partier. Men måske er tiden kommet til at supplere dette blik med metoder og analysestrategier, der giver os mulighed for at gå mere kvalitativt til værks. Dette ville om ikke andet facilitere en mere nuanceret forståelse af, hvordan nogle af de mest indflydelsesrige organisationer i nutidens samfund strukturerer sig selv og verden omkring os.

Rigtig god læselyst!

Litteratur

Barrling, K. (2013). Exploring the Inner Life of the Party: A Framework for Analysing Elite Party Culture. Scandinavian Political Studies, årg. 36(2), s. 177-199. https://doi.org/10.1111/j.1467-9477.2012.00302.x

Della Porta, D. (2013). Can Democracy Be Saved? Participation, Deliberation and Social Movements. Cambridge: Polity Press.

Duverger, M. (1954). Political Parties: Their Organization and Activity in the Modern State. London: Methuen.

Falguera, E., Jones, S., og Ohman, M. (2014). Funding of Political Parties and Election Campaigns: A Handbook on Political Finance. Stockholm: IDEA.

Gauja, A. og Kosiara-Pedersen, K. (2019). Partiforskning i Komparativ Politik. Politik, årg. 22(2), s. 30-53. https://doi.org/10.7146/politik.v\%vi\%i.117705

Hardt, M., og Negri, A. (2017). Assembly. Oxford: Oxford University Press.

Hume, D. (2002 [1742]). Of parties in general. I: S. Scarrow (red.), Perspectives on Political Parties: Classic Readings. New York: Palgrave Macmillan, s. 33-36.

Husted, E., og Plesner, U. (2017). Spaces of Open-Source Politics: Physical and Digital Conditions for Political Organization. Organization, årg. 24(5), s. 648-670. https://doi.org/10.1177/1350508417713215

Husted, E. (2019). Party Organization in the Digital Age. Ephemera: Theory and Politics in Organization, årg. 19(3), s. 651-662.

Husted, E. (2018). 'Some Have Ideologies, We Have Values': The Relationship Between Organizational Values and Commitment in a Political Party. Culture and Organization, s. 1-21. https://doi.org/10.1080/14759551.2018.1518325

Ignazi, P. (2017). Party and Democracy: The Uneven Road to Party Legitimacy. Oxford: Oxford University Press. 
Katz, R. S., og Mair, P. (1995). Changing Models of Party Organization and Party Democracy: The Emergence of the Cartel Party. Party Politics, årg. 1(1), s. 5-28. https://doi.org/10.1177/1354068895001001001

Katz, R. S., og Mair, P. (1992). Party Organizations: A Data Handbook on Party Organizations in Western Democracies, 1960-90. London: Sage.

Katz, R. S., og Mair, P. (1994). How Parties Organize: Change and Adaption in Party Organizations in Western Democracies. London: SAGE.

Mason, P. (2013). Why It's STILL Kicking Off Everywhere: The New Global Revolutions. London: Verso Books.

Michels, R. (1915). Political Parties: A Sociological Study of the Oligarchical Tendencies of Modern Democracy. New York: Dover Publications.

Moufahim, M., Reedy, P., og Humphreys, M. (2015). The Vlaams Belang: The Rhetoric of Organizational Identity. Organization Studies, årg. 36(1), s. 91-111. https://doi.org/10.1177/0170840614546149

Newton, K., Stolle, D., og Zmerli, S. (2018). Social and Political Trust. I: E. Uslaner, red., The Oxford Handbook of Social and Political Trust. Oxford: Oxford University Press, s. 37-56. https://doi.org/10.1093/oxfordhb/9780190274801.013.20

Noel, H. (2010). Methodological Issues in the Study of Political Parties. I: The Oxford Handbook of American Political Parties and Interest Groups. Oxford: Oxford University Press, s. 57-76. https://doi.org/10.1093/oxfordhb/9780199542628.003. 0004

Ostrogorski, M. (1902). Democracy and the Organization of Political Parties. New York: Macmillan.

Panebianco, A. (1988). Political Parties: Organization and Power. Cambridge: Cambridge University Press.

Pavía, J. M., Bodoque, A., og Martín, J. (2016). The Birth of a New Party: Podemos, a Hurricane in the Spanish Crisis of Trust. Open Journal of Social Sciences, årg. 4(9), s. 67-86. https://doi.org/10.4236/jss.2016.49008

Ringel, L. (2019). Unpacking the Transparency-Secrecy Nexus: Frontstage and Backstage Behaviour in a Political Party. Organization Studies, årg. 40(5), s. 705-723. https://doi.org/10.1177/0170840618759817

Ringel, L., Schank, J., Krichewsky, D. og Brichzin, J. (2019). Unlocking the Potential of Party Research: Bringing Sociology Back In. Politik, årg. 22(2), s. 54-74. https://doi.org/10.7146/politik.v\%vi\%i.117706

Rosavallon, P. (2008). Counter-Democracy: Politics in the Age of Distrust. Cambridge: Cambridge University Press.

Scarrow, S., og Webb, P. (2017). Investigating Party Organization: Structures, Resources, and Representative Strategies. I: Scarrow, S. Webb, P. og Poguntke, T., red., Organizing political parties. Oxford: Oxford University Press, s. 1-30. https://doi.org/10.1093/oso/9780198758631.003.0001 
Schwartz, S. A. (2019). Sociale Mediers Rolle indenfor Politisk Kommunikation: Et Litteraturstudie. Politik, årg. 22(2), s. 75-105. https://doi.org/10.7146/politik.v\%vi\%i. 117707

Solijonov, A. (2016). Voter Turnout Trends around the World. Stockholm: IDEA.

Tormey, S. (2015). The End of Representative Politics. Cambridge: Polity Press.

Van Biezen, I. (2012). Constitutionalizing Party Democracy: The Constitutive Codification of Political Parties in Post-war Europe. British Journal of Political Science, årg. 42(1), s. 187-212. https://doi.org/10.1017/S0007123411000263

Van Biezen, I., Mair, P., og Poguntke, T. (2012). Going, Going, . . Gone? The Decline of Party Membership in Contemporary Europe. European Journal of Political Research, årg. 51(1), s. 24-56. https://doi.org/10.1111/j.1475-6765.2011.01995.x

Wolkenstein, F. (2019). The Political Theory of Parties. Politik, årg. 22(2), s. 10-29. https://doi.org/10.7146/politik.v\%vi\%i.117704 